\title{
Differential herbivore occupancy of fire-manipulated savannas in the Satara region of the Kruger National Park, South Africa
}

\begin{tabular}{|c|c|}
\hline \multicolumn{2}{|c|}{$\begin{array}{l}\text { Authors: } \\
\text { Thobile B. Dlamini1i, } \\
\text { Brian K. Reilly } 1 \text { (1) } \\
\text { Dave I. Thompson } \\
\text { Deron E. Burkepile } \\
\text { Judith M. Botha }{ }^{2} \text { ( } \\
\text { Anthony G. Rebelo }\end{array}$} \\
\hline $\begin{array}{l}\text { Affiliations: } \\
{ }^{1} \text { Department } \\
\text { Conservation, } \\
\text { University of } \\
\text { Pretoria, Sout }\end{array}$ & $\begin{array}{l}\text { f Nature } \\
\text { Tshwane } \\
\text { echnology, } \\
\text { Africa }\end{array}$ \\
\hline $\begin{array}{l}{ }^{2} \text { South African } \\
\text { Observation } \\
\text { (SAEON), Ndlc } \\
\text { Phalaborwa, S }\end{array}$ & $\begin{array}{l}\text { Environmental } \\
\text { etwork } \\
\text { vu Node, } \\
\text { outh Africa }\end{array}$ \\
\hline $\begin{array}{l}{ }^{3} \text { School of Ge } \\
\text { Archaeology a } \\
\text { Environmenta } \\
\text { University of } \\
\text { Witwatersran } \\
\text { Johannesburg }\end{array}$ & $\begin{array}{l}\text { graphy, } \\
\text { nd } \\
\text { Studies, } \\
\text { he } \\
\text { 'South Africa }\end{array}$ \\
\hline $\begin{array}{l}{ }^{4} \text { Department } \\
\text { Evolution, ano } \\
\text { Biology, Unive } \\
\text { California, Sar } \\
\text { United States }\end{array}$ & $\begin{array}{l}\text { Ecology, } \\
\text { Marine } \\
\text { rsity of } \\
\text { ta Barbara, }\end{array}$ \\
\hline $\begin{array}{l}{ }^{5} \text { Scientific Ser } \\
\text { African Nation } \\
\text { Skukuza, Sout }\end{array}$ & $\begin{array}{l}\text { ices, South } \\
\text { al Parks, } \\
\text { Africa }\end{array}$ \\
\hline $\begin{array}{l}\text { 65outh African } \\
\text { Biodiversity In } \\
\text { Brummeria, P } \\
\text { South Africa }\end{array}$ & $\begin{array}{l}\text { National } \\
\text { stitute, } \\
\text { etoria, }\end{array}$ \\
\hline $\begin{array}{l}\text { Correspondin } \\
\text { Thobile Dlami } \\
\text { swazilious@g }\end{array}$ & $\begin{array}{l}\text { sauthor: } \\
\text { hi, } \\
\text { nail.com }\end{array}$ \\
\hline $\begin{array}{l}\text { Dates: } \\
\text { Received: } 14 \\
\text { Accepted: } 20 \\
\text { Published: } 26\end{array}$ & $\begin{array}{l}\text { ct. } 2019 \\
\text { Aug. } 2020 \\
\text { Oct. } 2020\end{array}$ \\
\hline Read online: & \\
\hline 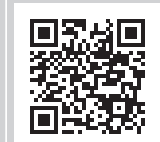 & $\begin{array}{l}\text { Scan this QR } \\
\text { code with your } \\
\text { smart phone or } \\
\text { mobile device } \\
\text { to read online. }\end{array}$ \\
\hline
\end{tabular}

The Kruger National Park's (KNP) long-running experimental burn plots (EBPs) have a history of research projects, which improve the understanding of fire in savanna ecosystems. Using data from KNP's aerial censuses (2005-2016) and in situ dung count data (2008-2017), this study assessed (1) herbivore densities on the Satara, N'Wanetsi and Marheya EBPs, on annual, triennial and no-burn treatments and across pre-, during and post-drought climate conditions; (2) herbivore densities of these EBPs relative to their non-manipulated surroundings and (3) the extent to which distance to water and rainfall influence ungulate densities. The results revealed that herbivore mean density differed significantly between the three EBPs of Satara and across their fire treatments. N'Wanetsi showed the highest density (0.30 animals/ha), whilst the lowest was found at Marheya (0.12 animals/ha). Overall, pre-drought density was higher on the annual plots (0.56 animals/ha), whilst higher post-drought density was evidenced on the triennial plots ( 0.80 animals $/ \mathrm{ha})$. On average, there were significantly higher herbivore densities on the EBPs (2.54 animals/ha) compared to the surrounding matrix at the larger scales of the Satara management section ( 0.15 animals/ha) and the central KNP (0.18 animals/ha). A positive correlation between herbivore mean density estimate and distance to water was shown. However, grazer mean density across fire treatments was strongly correlated to rainfall.

Conservation implications: Given the variation in fire regimes and their application, and the non-uniform and elevated herbivore densities of the EBPs, inferences from the EBPs cannot be made to the larger KNP. The trials should rather be viewed as an isolated, fire herbivory experiment. It is also recommended to align the experiment with South African National Parks' mandate by including biodiversity parameters like small mammals and insects in the monitoring of the plots.

Keywords: conservation; protected areas; ecosystem management; ecology; fire; herbivore densities; EBPs.

\section{Introduction}

Fire has long been considered an essential determinant of vegetation structure in savanna ecosystems (Sankaran \& Hanan 2008:17) and is frequently utilised as a management tool by conservationists. Changes in fire management in southern Africa over the past century reflect an increasing level of ecological consideration (Van Wilgen 2009:105), partially through the insight of manipulations such as the experimental burn plots (EBPs) in the Kruger National Park (KNP), South Africa. This fire experiment began in 1954 (Biggs et al. 2003:46) and has facilitated research projects on fire ecology in savanna ecosystems (Govender, Trollope \& Van Wilgen 2006:43). Fire extent, frequency and burn shape influence wildlife distributions across landscapes (Cromsigt, Archibald \& Owen-Smith 2017:47; Roberts 2008:1). Moreover, spatially patchy fire drives the spatial and temporal distribution of grazers, in particular, to congregate on immediate post-fire patches (McGranahan \& Kirkman 2013:176). Burning affects forage quality and quantity as well as animal behaviour and diet (Roberts 2008:1). Fire frequency further influences ungulate distribution through altered predation risk (Burkepile et al. 2013:139). At a landscape scale, fire reduces plant biomass (Hanan et al. 2008:171), resulting in temporary displacement of herbivores. Fire affects nutrient cycling (Van der Vijver, Proot \& Prins 1999:173) and soil organic nitrogen and carbon (Holdo et al. 2009:115), which influence

How to cite this article: Dlamini, T.B., Reilly, B.K, Thompson, D.I, Burkepile, D.E., Botha, J.M. \& Rebelo, A.G., 2020, 'Differential herbivore occupancy of fire-manipulated savannas in the Satara region of the Kruger National Park, South Africa', Koedoe 62(1), a1603. https://doi.org/10.4102/koedoe.v62i1.1603

Copyright: @ 2020. The Authors. Licensee: AOSIS. This work is licensed under the Creative Commons Attribution License. 
ecosystem productivity. It also modifies plant species composition (Anderson et al. 2007:343) and diversity (Belsky 1992:187). On the other hand, herbivores also drive changes in vegetation cover (Holdo et al. 2009:7). Thus, understanding fire's influence for the management of grazers is essential (Eby et al. 2014:1196). Post-fire stimulation of plant nutrients is thought to benefit grazing mammals (Eby et al. 2014:1198) as plant re-growth is higher in $\mathrm{Ca}, \mathrm{P}, \mathrm{Mg}$ and $\mathrm{K}$ and protein (Van der Vijver et al. 1999:173). Eby et al. (2014:1196) argued that herbivores are attracted to burned patches due to forage quality, rather than a decrease in predation risk. Woolfolk et al. (1975:190) and Anderson et al. (2007:343) reported a greater body mass gain in herbivores on post-burn areas. Fire may affect ungulate density and, together with annual rainfall and distance to water drives herbivore densities and distribution in savannas. Artificial surface water provision is widely practised in South African conservation. Access to water constrains herbivore movement and alters their distribution, particularly during drier periods (Bleich, Marshal \& Andrew 2010:638; DeLeeuw et al. 2001:297; Smith et al. 2007:85). Reduced rainfall in drier habitats has an impact on the life history characteristics, physiology and composition of plants and animals (Chesson et al. 2004:236). Rainfall not only provides water for herbivores but also drives forage quality and quantity (Marshal, Krausman \& Bleich 2005:360).

This study aimed to (1) quantify herbivore (buffalo, impala, kudu, giraffe, wildebeest and zebra) densities on the KNP Satara EBPs relative to surrounding control areas (central KNP and Satara management section); (2) relate fire frequencies to herbivore densities and (3) track species density changes across the EBPs over time and across rainfall (pre-, during and post-drought) to relate herbivore densities to mean distance to water and rainfall $(\mathrm{mm})$.

\section{Materials and methods Study area}

The KNP (1 948528 ha) is located in the low-lying savannas of the eastern Limpopo and Mpumalanga provinces of South Africa. Mozambique lies to the east and Zimbabwe to the north (Van Wilgen et al. 2000:167). The study was conducted on the controlled EBPs of the Satara region in the KNP. The vegetation community of the area is described as a Sclerocarya birrea-Vachellia (previously Acacia) nigrescens savanna (Gertenbach 1983:11). Common woody plants include V. nigrescens, S. birrea and Pterocarpus rotundifolius (Shackleton \& Scholes 2000:76). The shrub layer is dominated by Dichrostachys cinerea, Flueggea virosa and Grewia sp. The area is underlain by basalts with eutrophic fertile clay soils (Gertenbach 1983:11). Mean annual rainfall is $548 \mathrm{~mm}$ (Shackleton \& Scholes 2000:76), with most of the precipitation falling between November and February (Strydom et al. 2013:19). The region experiences variable annual rainfall, with a recent drought $<30 \%-40 \%$ of long-term average KNP rainfall experienced between 2015 and 2016 (Smith \& Bond 2020:120)

\section{Methodology}

The study site comprised three burn strings, namely, Satara, Marheya and N'Wanetsi, each comprising 14 plots, each with different fire treatments (Biggs et al. 2003:46). The treatments consist of five biennially burned plots, five triennially burned plots and single annual, quadrennial, sexennial and no-burn plots. Each string included one additional fire exclusion plot. Within the five biennial and triennial treatments, the season of burn varied, and a plot was burnt in one of each of February, April, August, October or December fire seasons. Annual plots were burnt in August each year, and the quadrennial and sexennial burned plots were burnt in October. This study focussed on herbivore densities at the August annual and triennial burn treatments in each string, as well as the control plots. Treatment plots were 6 ha -12 ha in size and arranged in strips parallel to the long axis of each string (Shackleton \& Scholes 2000:76). Within each string, treatments were randomly assigned to plots within strips (called burn blocks) (Shackleton \& Scholes 2000:76). The control plots were considerably larger and varied between 500000 ha and 100000 ha.

The density of buffalo, giraffe, impala, kudu, zebra and wildebeest in the control plots, for the period 2005-2016, was determined using the KNP's aerial census data. These data were collected using the protocol detailed in Kruger et al. (2008:371). The census data were clipped, using QGIS 2.2 into different strata of decreasing spatial scale, that is, central KNP (Marula North region: \pm 494594 ha) and the Satara management section ( \pm 91404 ha) prior to density estimation. Species density was estimated using the programme DISTANCE 6 per determined scale.

Relative herbivore use was derived from data generated during the 2008-2013 and 2016-2017 dung surveys on the different fire treatments, as detailed by Burkepile et al. (2013:136). In brief, data were collected from a series of $50 \mathrm{~m} \times 4 \mathrm{~m}$ transects established parallel to the short axis of each burn plot, with seven (2008-2013) and five (2016-2017) transects per plot. Herbivore dung piles encountered on transects in January, March and May of each survey year from 2008 to 2013 and monthly in 2016-2017 were identified to the species level. Once counted, dung was removed from each transect to avoid recounting during subsequent surveys. The mean number of dung piles per species was calculated for each transect in each burn plot and averaged across surveyed periods. Dung density estimates per species were converted to species density estimates following the method put forth by Bowland and Perrin (1994:505) and Smith (2012):

$D=\frac{N \times 0.02}{T \times D R}$,

(Eqn 1)

where, for each species, $D=$ density (number/ha), $N=$ dung piles (number), $T=$ interval between transect clearance and assessment (days), $D R=$ defecation rate (number of dung piles deposited per day) and a constant 0.02. Dung piles deposited per day were determined as the number of dung piles per species divided by the total number of transects 
multiplied by time. Dung decay rate was not included in species density estimates as the time interval between visits ( $<3$ month) was too short for dung to have decayed in semiarid savanna (Plumptre 2000:356).

For the determination of mean distance to water sources, Google Earth Pro was used to measure the distance from the furthest corner of each plot on individual burn strings to active and accessible water sources, both perennial and nonperennial (in 2016-2017), including rivers and artificial water points. Mean distance was calculated by summing the distances to water per burn string, divided by the total number of active water sources. The maximum and minimum distances were also indicated. Annual rainfall (2005-2017) data for the Satara section were used, as there were no data for individual burn strings. These data were provided by the KNP.

\section{Statistical analyses}

Data were transformed (Fowler, Cohen \& Javis 2009:179) using square root transformation as the variance of the data was approximately equal to the mean, indicating a Poisson distribution. Each observation $(x)$ was replaced by $\sqrt{x}$ and zero counts were replaced by $\sqrt{x}+0.05$. All analyses for dung counts were performed using programme $\mathrm{R}$ 3.2.2. DISTANCE 6 was used to derive density estimates from aerial counts. A single-factor analysis of variance (ANOVA) was utilised to determine significant differences between estimates. The Tukey honest significant differences (Tukey HSD) post hoc test was applied for multiple comparisons of means to highlight differences in density estimates across fire treatments and burn strings. Pearson's correlation coefficient was used to quantify the relationship amongst density estimates, annual rainfall and mean distance to water.

\section{Ethical consideration}

The authors declare that ethical clearance was not required for this study.

\section{Results \\ Fire treatment}

Mean herbivore density estimates for all years and strings combined were highest on the triennial burn plots (0.24 animals/ha) and lowest on the no-burn plots (0.12 animals / ha) (Figure 1a). Analysis of variance and a post hoc HSD test across different rainfall conditions (pre-, during and post-drought) revealed a significant difference $(p=0.002)$ across fire treatments before the drought (2008-2013). Predrought herbivore mean density on the annual burn plots (0.56 animals /ha) was significantly higher than the triennial (0.33 animals $/$ ha) $(p=0.006)$ and no-burn (0.32 animals $/$ ha $)$ $(p=0.007)$ plots (Figure 1b). During the drought (2016), herbivore density estimates on the triennial burn plots were significantly ( $p=0.01)$ higher $(0.25$ animals $/$ ha $)$ than the annual burn plot's estimates (0.06 animals/ha) (Figure 1b). Post-drought (2017), the density estimates from the triennial burn plots were significantly ( $p=0.003)$ higher ( 0.80 animals / ha) than the no-burn plots (0.18 animals/ha) (Figure 1b). However, the annual (0.41 animals/ha) and no-burn plots were not significantly different $(p=0.09)$ in density estimates after the drought.

\section{Burn strings}

An ANOVA and a post hoc (Tukey HSD) test revealed significant differences $(p=0.001)$ in herbivore mean density estimates between individual burn strings. The N'Wanetsi burn string (Figure 2a) had significantly $(p=0.001)$ higher pooled (all years combined) density estimates (0.30 animals/ha), whilst the Marheya string showed the lowest density at 0.12 animals / ha $(p=0.03)$. Within burn string, a significant $(p=0.01)$ difference was shown for N'Wanetsi between fire treatments (Figure $2 b$ ). The triennial burn plots had a significantly higher (0.19 animals/ha) estimate, with the lowest shown for the no-burn (0.04 animals/ha) $(p=0.02)$ treatment plot (Figure 2b). Similarly, the Satara burn string revealed a

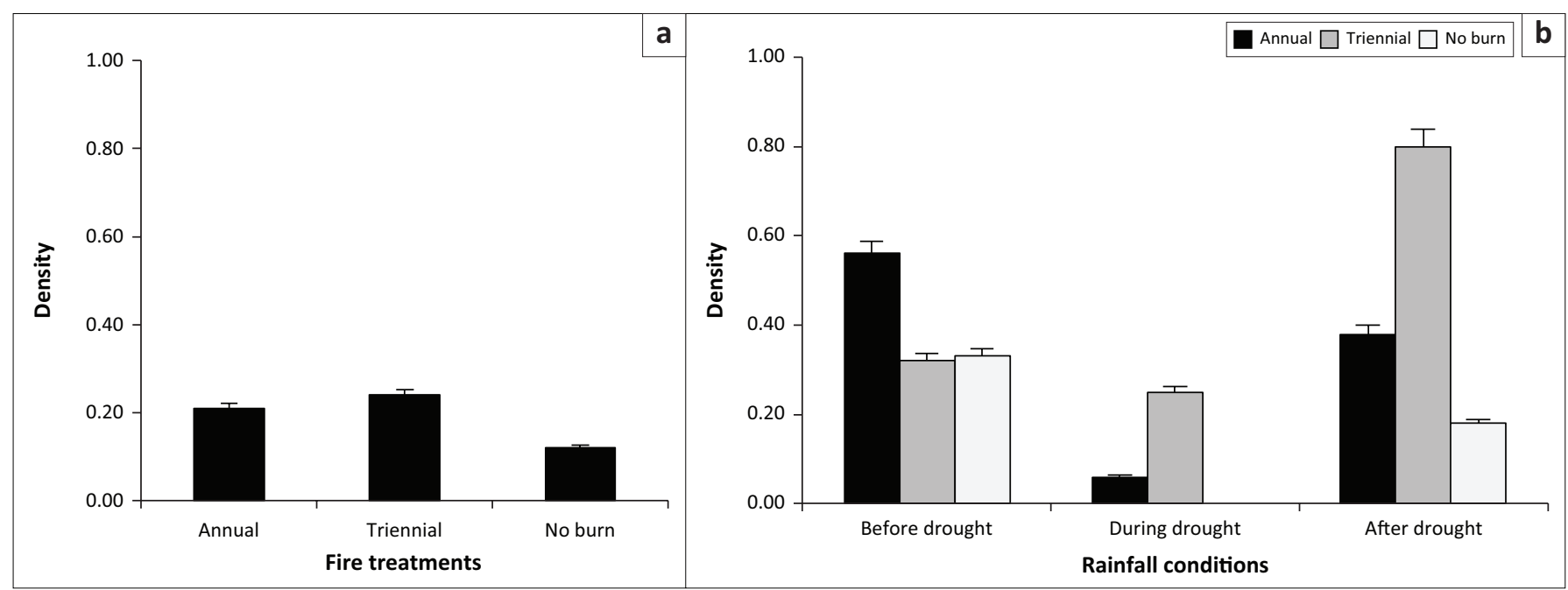

FIGURE 1: Pooled herbivore density estimates (a) for three fire treatments (annual burn, triennial burn and no-burn plots) on the Satara experimental burn plots. (b) Herbivores mean density estimate shown across rainfall conditions (before, during and after drought) and fire treatments (95\% confidence interval shown). 


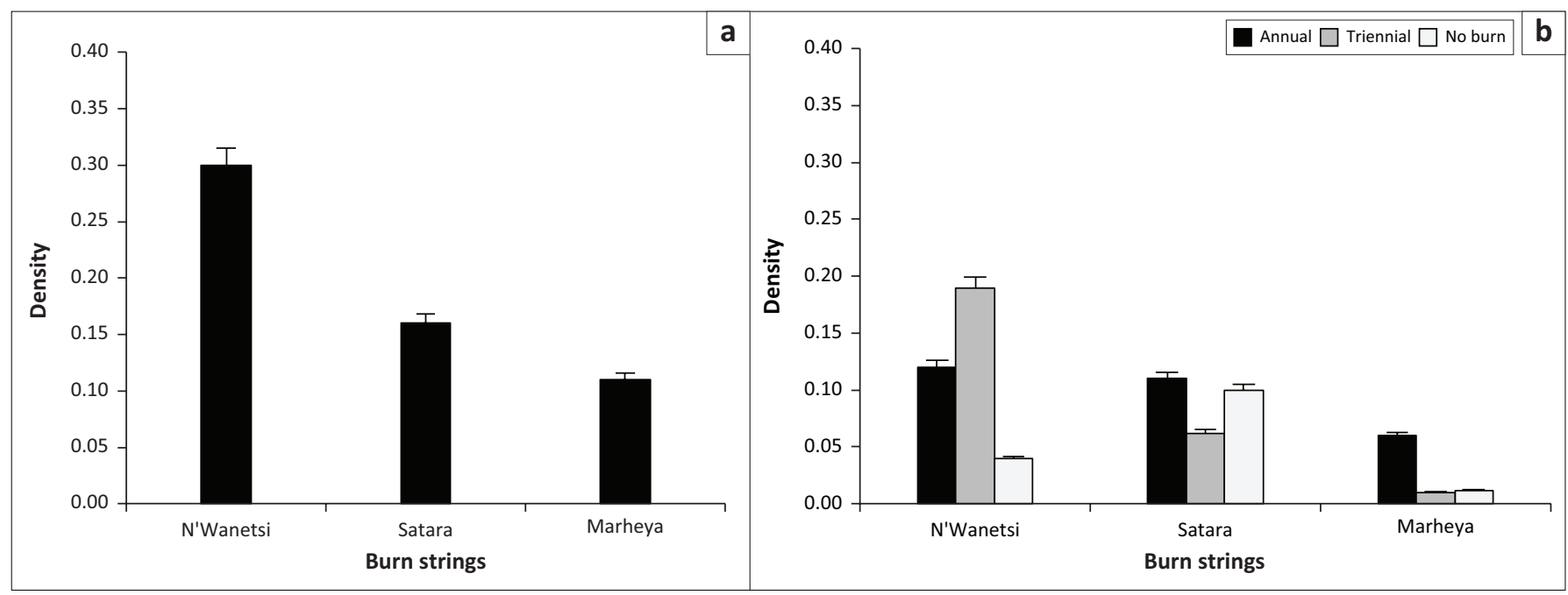

FIGURE 2: (a) Overall herbivore density estimates, on the experimental burn strings (N’Wanetsi, Satara and Marheya) of Satara, Kruger National Park, and (b) herbivore density estimates across fire treatments per burn string ( $95 \%$ confidence interval shown).

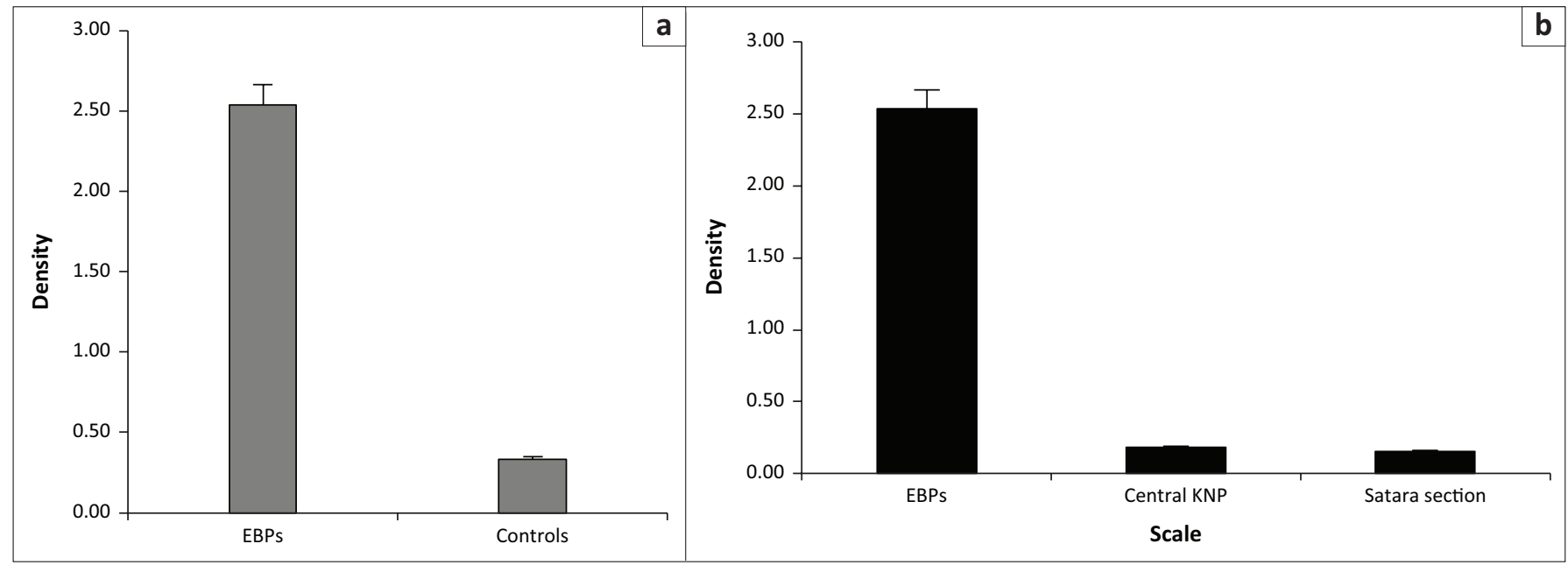

EBPs, experimental burn plots; KNP, Kruger National Park.

FIGURE 3: Overall herbivore density estimates compared (a) between experimental burn plot strings and non-manipulated control areas, and (b) amongst burn strings, central Kruger National Park and the Satara management section ( $95 \%$ confidence interval shown).

significant difference $(p=0.02)$ in herbivore density estimates across fire treatments (Figure 2b). Herbivore mean density estimates were significantly higher $(p=0.01)$ on the annual burn plots (0.11 animals/ha) and lowest on the triennial burn (0.06 animals/ha) plots. The no-burn plot revealed a density estimate of 0.10 animals / ha, similar to that of the annual burn plot. The Marheya string also revealed significant differences $(p=0.0003)$ across fire treatments (Figure 2b), with density estimates being significantly higher $(p=0.001)$ on the annual burn plot ( 0.06 animals $/$ ha) and lowest on the triennially burned plot (0.01 animals/ha).

\section{Experimental burn plots versus controls}

Herbivore mean density between fire treatments and the adjacent non-manipulated control areas suggests that, overall, the burn strings are preferred by herbivores compared to the control areas. The mean density estimate was seven times higher (2.54 animals/ha) on the burn strings than the non-manipulated control areas (0.33 animals /ha; $p=001$ ) (Figure 3a). Furthermore, the mean density estimate from the burn strings was 14 times higher than central KNP (0.18 animals/ha) and 16 times higher than the Satara management section (0.15 animals / ha; $p=001$ ) (Figure 3b).

\section{Distance to water and rainfall}

On average, the burn strings were at a mean distance of $3.47 \mathrm{~km}$ from active water sources in 2016-2017. Pearson's correlation coefficient revealed a weak correlation $(r=0.57)$ between the mean distance to water and water abundance $(r=0.50)$ with the estimated herbivore density across the burn strings. Marheya was shown with the lowest herbivore density estimate despite having the most abundant (8), and second closest active water source. A minimum of $0.30 \mathrm{~km}$ and a maximum of $6.78 \mathrm{~km}$ to water were indicated, with a mean distance of $2.60 \mathrm{~km}$. The N'Wanetsi burn string had the highest herbivore density estimate, but the 
fewest (2) and the farthest active water sources (range, $5.00 \mathrm{~km}-6.42 \mathrm{~km}$; mean, $5.71 \mathrm{~km}$ ). The Satara burn string had an intermediate herbivore density estimate and an intermediate number of active water sources (5), but the shortest mean distance to water $(1.99 \mathrm{~km}$; range, $0.60 \mathrm{~km}-$ $4.96 \mathrm{~km})$. Therefore, the abundance of water sources and their distance to the burn strings showed a petite effect on herbivore density.

Rainfall showed a significant impact on herbivore densities across fire treatment plots and per feeding guild (Figure 4). A strong correlation $(r=0.96)$ (Figure 4a) between herbivore densities on the no-burn and annual burn $(r=0.71)$ plots and annual rainfall was evident. Disaggregation by feeding guild across fire treatments revealed rainfall and the density of grazers to be strongly correlated $(r=0.91)$ (Figure $4 \mathrm{~b})$ on annual burn plots. Similarly, on the no-burn plots, a strong correlation ( $r=0.85$ ) (Figure $4 \mathrm{~d}$ ) was shown between the density of grazers and rainfall. A proportional strong correlation $(r=0.84)$ (Figure 4c) was shown between rainfall and the density of grazers and browsers on the triennial burn plots. Browser estimates also revealed a positive, but weak, correlation on the annual burn plots $(r=53)$. Conversely, mixed feeders showed a correlation $(r=65)$ with rainfall on the triennial burn plots and on the no-burn plots $(r=55)$. This illustrates the significance of annual rainfall as a driver of herbivore densities in fire-prone savannas.

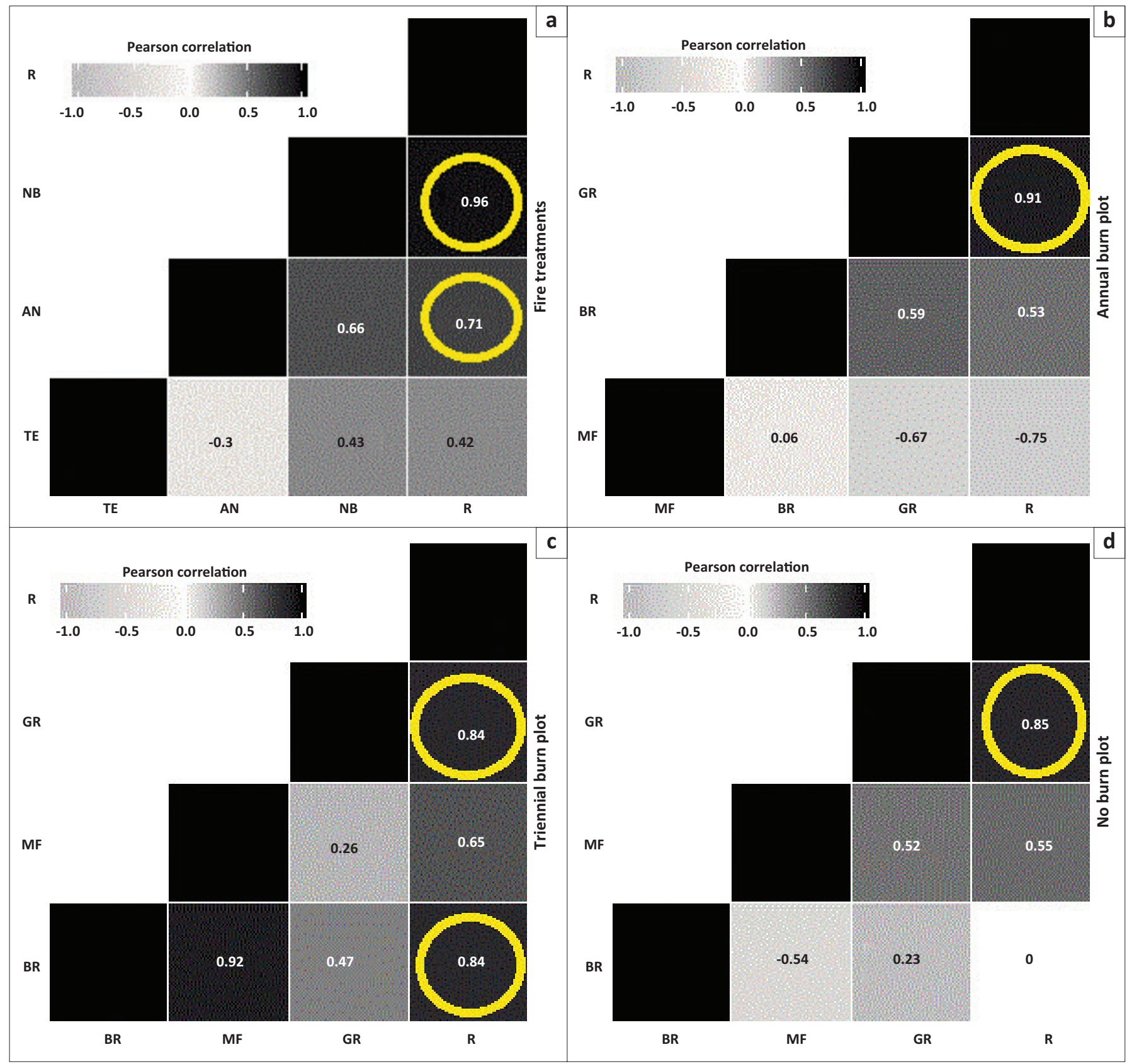

FIGURE 4: Pearson's correlation showing the relationship between rainfall (R) and overall herbivore density estimate (MF, mixed feeders; BR, browsers and GR, grazers), across all fire treatments (a), and per individual fire treatment, (b) annual (AN), (c) triennial (TE) and (d) no burn (NB), plots of Satara KNP. 


\section{Discussion}

Fire showed a vast influence on herbivore densities across the EBPs. The higher collective density of herbivores on the EBPs compared to the non-fire manipulated areas of the larger Central KNP and Satara section is because of variances in fire regimes. A decrease in abundance of herbs and small shrubs was found by Morrison et al. (1995:240) on infrequently burned landscapes such as the non-fire manipulated parts of KNP. Fire regimes influence changes in habitat structure, plant species composition and palatability (Lyon et al. 2000:23). A study by Morrison et al. (1995:144) suggests that animals are attracted to an area because of forage quality rather than the fear of predation. Therefore, the EBPs may be dominated by palatable plant species to attract higher herbivore densities compared to their non-fire manipulated surroundings.

The significant differences on herbivore densities across individual burn strings ( N'Wanetsi, Satara and Marheya) and their fire treatment plots suggest differences in the temporal nature of each. Selective herbivore use of the EBPs may be because of the differences in vegetation quality and quantity caused by fire frequency and intensity and rainfall (Shackleton \& Scholes 2000:81). Therefore, vegetation palatability across these burn strings may differ, causing herbivores to congregate and forage selectively. Selective foraging of herbivores influences the distribution and biomass of plants, in turn affecting fire regime attributes (Smith et al. 2013:72). The annual burn plots of the Satara EBPs have been documented with low grass species richness than the triennial burn plots because of fire frequency and intensity (Shackleton \& Scholes 2000:79). Therefore, the continued burning of the annual plots, whilst exposed to higher densities, may have decreased grass species richness even further in the past decade. This causes a shift from annual to triennial plots on overall herbivore densities to occur. An island study conducted by Feeley and Terborgh (2005:116) suggests that higher herbivore densities in annually burned areas cause a shift in the plant communities towards unpalatable plant species over time. Additionally, annually burned plots exposed to grazing because of high herbivore densities reduce the abundance of palatable plant species relative to unpalatable ones (Jourbert et al. 2014:126). Therefore, plots become dominated by fire-tolerant plant species with reduced composition (Boakye et al. 2014:603), in turn affecting herbivore densities. However, burning at a 3-year interval supports both fire-tolerant and fire-intolerant species with high species composition (Boakye et al. 2014:603), further facilitating higher herbivore densities and composition. Research also outlines that fire frequency and grazing intensity have a detrimental effect on plant species diversity, composition and their nutritional levels (Jourbert et al. 2014:126). Palatable grass species like Panicum maximum were reported to increase in infrequently burned areas like triennial burn plots (Smith et al. 2013:72), whereas Urochloa mosambicensis was reported to increase in abundance in intermediate and greater fire intensity (Smith et al. 2013:80).
Therefore, higher herbivore densities shifting to triennially burned plots suggest that herbivores follow quality forage and diverse plant species that the annual plot may have lacked. Moreover, a 3-year interval burning results in highvegetation biomass, improving the proportion of palatable species (Jourbert et al. 2014:128) compared to the annual burn frequency. However, an increase in the relative abundance of unpalatable species because of annual burning results in a decline in quality of leaf litter, causing a decline in nutrient revenues and primary production rates (Pastor \& Naiman 1992:690). This motivates selective foraging of herbivores, whilst directly affecting herbivore populations across treatment plots. Although the loss of grass biomass with frequent burning is attributed to reduced plant diversity (Auld \& Denham 2006:15; Snyman 1998:645), herbivore densities are also affected.

Water abundance and mean distance to water showed a slight effect on the herbivore densities on the EBPs. However, this does not exclude abundance of water as the cause of high herbivore congregations on the EBPs but may indicate that it is not the only factor. Factors like rainfall over the medium term drive forage quality and quantity in African savanna ecosystems (Peel \& Bothma 1995:41; Venter, Scholes \& Eckhardt 2003:5). Herbivores respond indirectly to this driver, with $87 \%$ of the variance in large ungulate biomass being explained by rainfall and fire (Fritz \& Duncan 1994:77). The strong correlation between rainfall and herbivore densities on the EBPs coincides with Fritz and Duncan (1994:77) that rainfall is significantly important to herbivore densities in fire-prone semi-arid savanna ecosystems. Rainfall forms the archetype that determines the moisture and nutrients available to plants, therefore, influencing the way habitats are selectively utilised by herbivore populations. Hence, impacts on the EBP trial cannot be attributed to fire alone but to a combination of fire, past herbivory and rainfall. In events like 'drought', where rainfall is scarce, changes in different functional plant responses are experienced (Silver et al. 2013:17), indirectly causing changes in herbivore population densities and distributions. Ecosystems like semi-arid savannas with intermittent low annual rainfall seasonally modify $\mathrm{CO}_{2}$ and $\mathrm{N}$ cycles, resulting in poor water and mineral uptake, hindering growth and causing reduced litter decomposition, alternately altering above ground net primary production (Silver et al. 2013:17), in turn influencing changes in herbivore densities before and after a drought period.

\section{Conclusion}

The EBPs are preferred grazing patches for buffalo, giraffe, impala, kudu, zebra and wildebeest, compared to the nonfire manipulated surrounding areas. Our findings suggest that the differences in the burn strings of Satara may not only be because of fire but also because of higher herbivore densities. Higher herbivore densities impose increased grazing pressure and this questions the level of impact caused by the fire and grazing on the EBPs or the impact of both events in succession (Shackleton \& Scholes 2000:80). Moreover, the vast differences between the EBPs, Satara 
section and the central KNP in herbivore densities validate that they are different in the nature of fire regimes and applications, and thus cannot be used to make informed decisions on the broader central KNP or Satara management section. This motivates management to reconsider the EBPs as a fire-herbivory experiment, especially when the density estimate is more than seven times higher in places. Although fire proved to have an influence on the herbivore densities on the EBPs, factors like rainfall may have contributed to some extent, as the correlation between herbivore densities and rainfall was stronger. This further accentuates that fire and rainfall are critical drivers of herbivore densities on the EBPs and fire-prone semi-arid savanna ecosystems. Nonetheless, results from this study may be influenced by the 2015-2016 drought period, as this event can affect an ecosystem to some degree.

\section{Recommendations}

Careful interpretation of results is needed to unbundle the effects of fire, herbivory and rainfall, all of which may have a greater impact on the EBPs. The annual treatments have not burned effectively since 1996 compared to the triennials because of inadequate fuel load to sustain a fire. In some cases, the herb layer is too wet and green to facilitate and enable burning. This disrupts the burning schedule for the fire treatment. In addition, burning the annuals in August no longer seems effective, suggesting a revised burning season or a renaming of the treatment as near-annual burns rather than annual burns. The EBPs being focal points for research in $\mathrm{KNP}$, long term rainfall data for individual burn strings should be available to prevent researchers from relying on regional or section data. Putting up rain gauges on the EBPs for long-term data collection is advisable, as regional rainfall has proven to have a greater effect on herbivore densities within the EBPs.

\section{Acknowledgements Competing interests}

The authors have declared that no competing interests exist.

\section{Authors' contributions}

All authors contributed equally to this work.

\section{Funding information}

This study was funded by the South African National Biodiversity Institute (SANBI) and the Department of Nature Conservation at Tshwane University of Technology (TUT). The financial assistance of the National Research Foundation (NRF) and the South African Environmental Observation Network (SAEON) towards this research is also acknowledged.

\section{Data availability statement}

Data of the study belongs to the South African Environmental Observation Network and therefore access can only be permitted by this organisation.

\section{Disclaimer}

The views and opinions expressed in this article are those of the authors and do not necessarily reflect the official policy or position of any affiliated agency of the authors.

\section{References}

Anderson, T.M., Ritchie, M.E., Mayemba, E., Eby, S., Grace, J B. \& McNaughton, S.J., 2007 'Forage nutritive quality in the Serengeti ecosystem: The roles of fire and herbivory', The American Naturalist 170(3), 343-357. https://doi.org/10.1086/520120

Auld, T.D. \& Denham, A.J., 2006, 'How much seed remain in the soil after a fire?', Plant Ecology 187(1), 15-24. https://doi.org/10.1007/s11258-006-9129-0

Belsky, J.A., 1992, 'Effects of grazing, competition, disturbance and fire on species composition and diversity in grassland communities', Vegetation Science 3(2), 187-200. https://doi.org/10.2307/3235679

Biggs, H.C. \& Rogers, K.R., 2003, 'An adaptive system to link science, monitoring and management in practice', in J.T. Du Toit, K.H. Rogers \& H.C. Biggs (eds.), The Kruger experience: Ecology and management of savanna heterogeneity, pp. 59-80, Island Press, Washington, DC.

Bleich, V.C., Marshal, J.P. \& Andrew, N.G., 2010, 'Habitat use by a desert ungulate: Predicting effects of water availability on mountain sheep', Journal of Arid Environment 74(6), 638-645. https://doi.org/10.1016/j.jaridenv.2009.10.019

Boakye, M.K., Little, I.T., Panagos, M.D. \& Jansen, R., 2014, 'Effects of burning and grazing on plant species percentage cover and habitat condition in the highland grassland of Mpumalanga province, South Africa', Journal of Animal and Plant Science 23(2), 603-610

Bowland, A.E. \& Perrin, M.R., 1994, 'Density estimate methods for blue duikers (Philantomba monticola) and red duiker (Cephalophus natalensis) in Natal, South Africa', Journal of African Zoology 108, 505-519.

Burkepile, D.E., Burns, C.J., Tambling, E.A., Buis, G.M., Govender, N., Nelson, V. et al., 2013, 'Habitat selection by large herbivores in a Southern African savanna: The relative roles of bottom-up and top-down forces', Ecosphere 4(11), 139. https:// doi.org/10.1890/ES13-00078.1

Chesson, P., Gebauer, R.L., Schwinning, S., Huntly, N., Wiegand, K., Ernest, M.S. \& Weltzin, J.F., 2004, 'Resource pulses, species interactions, and diversity maintenance in arid and semi-arid environments', Oecologia 141(2), 236-253. $\mathrm{https} / / /$ doi.org/10.1007/s00442-004-1551-1

Cromsigt, J.P.G.M., Archibald, S. \& Owen-Smith, R.N., 2017, Conserving Africa's megadiversity in the anthropocene: The Hluhluwe Imfolozi Park story, Cambridge University Press. London.

DeLeeuw, J., Maweru, M.N., Okello, O.O., Maloba, M., Nguru, P. \& Said, M.Y., 2001, 'Distribution and diversity of wildlife in northern kenya in relation to livestock and permanent water points', Bioogical Conservation 100(3), 297-306. https://doi. org/10.1016/S0006-3207(01)00034-9

Eby, S.L., Anderson, T.M., Mayembe, E.P. \& Ritchie, M.E., 2014, 'The effect of fire on habitat selection of mammalian herbivores: The role of body size and vegetation characteristics', Journal of Animal Ecology 83(5), 1196-1205. https://doi. org/10.1111/1365-2656.12221

Feeley K. \& Terborgh, J., 2005, 'The effect of herbivore density on soil nutrients and tree growth in tropical forest fragments', Ecology 86(1), 116-124. https://doi. tree growth in tropical
org/10.1890/03-0657

Fowler, J., Cohen, L. \& Javis, P., 2009, Practical statistics for field biology, 2nd edn., Wiley John and Sons, West Sussex.

Fritz, H. \& Duncan, P., 1994, 'On the carrying capacity for large ungulates of African savanna ecosystems', Proceedings of the Royal Society of London 256(1345), 77-82. https://doi.org/10.1098/rspb.1994.0052

Gertenbach, W.P.D., 1983, 'Landscapes of Kruger National Park', Koedoe 26, 9-121. https://doi.org/10.4102/koedoe.v26i1.591

Govender, N., Trollope, W.S. \& Van Wilgen, B.W., 2006, 'The effect of fire season, fire frequency, rainfall and management on fire intensity in savanna', Journal of

Hanan, N.P., Sea, W.B., Dangelmayr, G. \& Govender, N., 2008, 'Do fires in savannas consume woody biomass? A comment on approaches to modelling savanna dynamics', The American Naturalist 171(6), 851-856. https://doi. savanna dynamics,
org $/ 10.1086 / 587527$

Holdo, R.M., Sinclair, A.R.E., Dobson, A.P., Metzger, K.L., Bolker, B.M. \& Ritchie, M.E., 2009, 'A disease-mediated trophic cascade in the Serengeti and its implications for ecosystem', C.PLoS Biology 7(9), e1000210. https://doi.org/10.1371/journal. pbio. 1000210

Jourbert, L., Pryke, J.S. \& Samways, M.J., 2014, 'Annual burning drives plant community in remnant grassland ecological networks in an afforested landscape', South African Journal of Botany 92, 126-133. https://doi.org/10.1016/j.sajb.2014.02.009

Kruger, J.M., Reilly, B.K. \& Whyte, I.-J., 2008, 'Application of distance sampling to etimate population densities of large herbivores in Kruger National Park', Wildlife Research 35, 371-376.

Lyon, L.J., Huff, M.H., Hoper, R.G., Telfer, E.S., Schreiner, D.S. \& Smith, J.K., 2000 'Wildland fire in ecosystems', Wildland fire in ecosystems: effects of fire on fauna. USDA Forest Service Research; Pap. SE -234, pp. 23, Fort Collins, Colorado.

Marshal, J.P., Krausman, P.R. \& Bleich, V.C., 2005, 'Rainfall, temperature and forage dynamics affect nutritional quality of desrt mule deer forage', Rangeland Ecology and Management 58(4), 360-365. https://doi.org/10.2111/15515028(2005)058[0360:RTAFDA]2.0.CO;2 
McGranahan, D.A. \& Kirkman, K.P., 2013, 'Multifunctional rangeland in Southern Africa: Managing for production, conservation and resilience with fire and grazing', Land 2(2), 176-193. https://doi.org/10.3390/land2020176

Morrison, D.A., Cary, G.T., Pengelly, S.M., Ross, D.G., Mullins, B.J., Thomas, C.R. et al., 1995, 'Effects of fire frequency on plant species composition of sandstone communities in the Sydney region: Inter-fire interval and time-since-fire', Australia Journal of Ecology 20(2), 239-247. https://doi.org/10.1111/j.1442-9993.1995. tb00535.x

Pastor, J. \& Naiman, R.J., 1992, 'Selective foraging and ecosystem processes in boreal forests', The American Naturalist 139(4), 690-705. https://doi.org/10.1086/285353

Peel, M.J.S. \& Bothma, J.d.P., 1995, 'Comparison of accuracy of four methods commonly used to count impala', South African Journal of Wildlife Research 25(2), 41-43.

Plumptre, A.J., 2000, 'Monitoring mammal populations with line transect technique in African forests', Journal of Applied Ecology 37(2), 356-368. https://doi. org/10.1046/j.1365-2664.2000.00499.x

Roberts, L.S., 2008, 'Special issue: Fire and wildlife Interaction', Fire Ecology 4(2), 1-2. https://doi.org/10.4996/fireecology.0402001

Sankaran, M.R. \& Hanan, N.P., 2008, 'Woody cover in African savannas: The role of resources, fire and herbivory', Global Ecology \& Biogeography 17(2), 236-245. https://doi.org/10.1111/j.1466-8238.2007.00360.x

Shackleton, C.M. \& Scholes, R.J., 2000, 'Impact of fire frequency on woody community structure and soil nutrients in the Kruger National Park', Koedoe 43(1), 75-81. https://doi.org/10.4102/koedoe.v43i1.210

Silver, E.C., Albuquerque, M.B., Azevedo Neto, A.D. \& Silver Junior, C.D., 2013 'Drought and its consequences to plants from individual to ecosystem', in S. Akinci (ed.), Responses of organisms to water stress, pp. 17-47, In Tech, Croatia.

Smith, D., 2012, Inventory and monitoring toolbox: Animal pests: Faecal pellet counts, Department of Conservation, Te Papa Atawhai.

Smith, I.P.J. \& Bond, W.J., 2020, 'Observations on the natural history of a savanna drought', African Journal of Range \& Forage Science 37(1), 119-136. https://doi. org/10.2989/10220119.2020.1723695
Smith, I.P.J., Grant, C.C. \& Devereux, B.J., 2007, 'Do artificial water holes influence the way herbivores use the landscape? Herbivore distributions patterns around rivers and artificial surface water sources in a large African savanna park', Biological Conservation 136(1), 85-99. https://doi.org/10.1016/j.biocon.2006.11.009

Smith, M.D., Van Wilgen, B.W., Burns, C.E., Govender, N., Potgieter, A.L.F., Andelman, S et al., 2013, 'Long-term effects of fire frequency and season on herbaceous vegetation in savannas of the Kruger National Park, South Africa', Journal of Plant vegetation in savannas of the Kruger National Park, South $A$. $71-83$. https://doi.org/10.1093/jpe/rts014
Ecology

Snyman, H.A., 1998, 'Dynamics and sustainable utilization of the rangeland ecosystem in arid and semi-arid climates of Southern Africa', Journal of Arid Environment 39(4), 645-666. https://doi.org/10.1006/jare.1998.0387

Strydom, T., Riddell, E., Lorentz, S. \& Le Roux, P., 2013, 'The effects of long- term fire frequencies on soil hydralic properties in semi-arid savannas in Kruger National Park', MSc Thesis, Center for Water Resource Research, School of Agriculture, Earth and Environmental Sciences, Pietermaritzburg.

Van der Vijver, C.A.D.M., Proot, P. \& Prins, H.H.T., 1999, 'Causes of increased nutrient concetrations in post-fire regrowth in an East Afrcan savanna', Plant and Soil 214(1), 173-185. https://doi.org/10.1023/A:1004753406424

Van Wilgen, B.W., 2009, 'The evlolution of fire management in savanna protected areas in South Africa', South African Journal of Science 105(9/10). https://doi. org/10.4102/sajs.v105i9/10.107

Van Wilgen, B.W., Biggs, H.C., O'Regan, H. \& Mare, N., 2000, 'A fire history of the savanna ecosystems in the Kruger National Park, between 1941 and 1996', South African Journal of Science 96(4), 167-178.

Venter, F.J., Scholes, R.J. \& Eckhardt, H.C., 2003, 'The abiotic template and its associated vegetation pattern', in J.T. Du Toit, K.H. Rogers \& H.C. Biggs (eds.), The Kruger experience: Ecology and management of savanna heterogeneity, pp. 83-129, Island Press, Washington, DC

Woolfolk, J.S., Smith, E.F., Schalles, R.R., Brent, B.E., Harbes, L.H. \& Owensby, C.E., 1975, 'Effects of nitrogen fertilization and late-spring burning on bluestem range on diet and performance of steers', Journal of Rangeland Management 28(3), 190-193. https://doi.org/10.2307/3897523 